\title{
sciendo
}

Comparative Legilinguistics

vol. $39 / 2019$

DOI: http://dx.doi.org/10.14746/cl.2019.39.2

\section{THE BOLC FOR LEGAL TRANSLATIONS: A TRIAL LESSON}

\section{Patrizia GIAMPIERI, MSc.}

\author{
University of Camerino \\ School of Law \\ Via D'Accorso, 16 \\ 62032 Camerino (MC) \\ patrizia.giampieri@unicam.it
}

ORCID: https://orcid.org/0000-0003-4443-1593

\begin{abstract}
This article will explore how consulting the BoLC (Bononia Legal Corpus; Rossini Favretti, Tamburini and Martelli 2007) can be helpful and advantageous when tackling legal translations. To this aim, a 4-hour trial lesson with experienced translators was organized. Before the workshop, the participants translated a 300-word legal document issued within a civil case. Their translations (from English to Italian) were revised during the trial lesson, where the attendants learned how to consult the BoLC. They also used supplementary online resources, such as dictionaries and/or experts' blogs or fora. The article findings will remark that despite some drawbacks, such as the absence of POS tagging and lemmatization, and a quite complex search syntax, the BoLC helps dispel doubts and deliver outstanding translation work. Its main usefulness lies in the possibility of finding formulaic expressions and collocational use, which can be rather intricate in legal discourse.
\end{abstract}


Key words: corpus-based legal translations; online corpora; legal translations; corpus consultation; corpus linguistics; the BoLC (Bononia Legal Corpus)

\title{
TRADUZIONI GIURIDICHE E BOLC: UN CASO DI STUDIO
}

Riassunto: Il presente articolo verte sull'uso e consultazione del BoLC (Bononia Legal Corpus; Rossini Favretti, Tamburini e Martelli 2007) nelle traduzioni giuridiche. A tal scopo, si presenta una lezione di 4 ore tenuta con traduttori professionisti. Prima della lezione, i traduttori sono stati invitati a svolgere e consegnare una traduzione di un testo di 300 parole inerente ad una causa civile. Le loro traduzioni (dall'Inglese all'Italiano) sono state poi riviste e corrette durante la lezione, nella quale i partecipanti hanno appreso le tecniche e la sintassi di ricerca del BoLC. I traduttori hanno anche consultato altre risorse linguistiche reperibili online, quali dizionari, blog di esperti e forum. Questo articolo mostra come, nonostante la complessità della sintassi di ricerca, il BoLC può essere un utile strumento nelle traduzioni giuridiche, soprattutto perché permette di trovare espressioni formulaiche e collocazioni, che caratterizzano fortemente il linguaggio giuridico.

Parole chiave: traduzioni giuridiche; corpora per traduzioni giuridiche; consultazione di corpora; linguistica dei corpora; il BoLC (Bononia Legal Corpus)

\section{BOLC DO TLUMACZEŃ PRAWNYCH I PRAWNICZYCH: LEKCJA PRÓBNA}

\begin{abstract}
Abstrakt: W artykule dowiemy się, w jaki sposób BoLC (Bononia Legal Corpus; Rossini Favretti, Tamburini i Martelli 2007) może być pomocnym i korzystnym źródłem w thumaczeniu prawnym i prawniczym. W tym celu zorganizowano 4-godzinną lekcję próbną z doświadczonymi tłumaczami. Przed warsztatami uczestnicy przethumaczyli 300-wyrazowy dokument wydany $\mathrm{w}$ sprawie cywilnej. Ich tłumaczenia (z języka angielskiego na włoski) zostały poprawione podczas lekcji próbnej, w której uczestnicy nauczyli się konsultować swoje wyniki $\mathrm{z}$ BoLC. Korzystali również z dodatkowych zasobów internetowych, takich jak słowniki i/lub blogi eksperckie lub fora. Ustalenia w niniejszym artykule dowodzą, że pomimo pewnych wad, takich jak brak tagowania POS i lematyzacji oraz dość złożona składnia wyszukiwania, BoLC pomaga rozwiać wątpliwości i zapewnić zdumiewające wyniki w pracy przy thumaczeniu. Jego główna użyteczność polega na możliwości znalezienia wyrażeń konwencjonalnych i użycia kolokacyjnego, co może być dość skomplikowane w dyskursie prawnym.
\end{abstract}


Słowa klucze: badania korpusowe tłumaczeń prawnych i prawniczych; korpusy online; thumaczenia prawne i prawnicze; konsultacja z korpusem; językoznawstwo korpusowe; BoLC (Bononia Legal Corpus)

\section{Introduction}

English legal discourse is notoriously pedantic and archaic, mostly for reasons of "all-inclusiveness" (Bhatia 1993: 102; Coulthard and Johnson 2007: 38), but also on historical grounds (Tiersma and Solan 2012). It is rich in formulaic expressions (Bhatia, Langton and Lung 2004: 207) which present a "very rigid structure" (Tiersma and Solan 2012: 63). Many phrases are also composed of binomial expressions and complex prepositional phrases (Coulthard and Alison 2010: 10), as well as adverbial constructs with anaphoric or cataphoric values (Abate 1998: 14-16). Furthermore, legal documents written in English are hallmarked by very long sentences (Williams 2004), used to avoid ambiguity and misunderstandings (Tiersma and Solan 2012: 53), or to show solidarity between the members of the legal fraternity (Bhatia 1993: 102; Tiersma 1999: 69).

In light of the above, tackling English legal discourse can be challenging, particularly in view of the system-specificity of legal terms (De Groot and Van Laer 2008). This implies that each term should not only be rendered from a source into a target language, but it should also be adapted to the target legal system (provided that this is possible). As claimed by the literature, in fact, translators always struggle for the best translation candidates to use in a context; whereas lawyers are generally more interested in how comparable different legal systems are (Biel and Engberg 2013: 2).

It is self-evident that choosing the most adequate and reliable language tool is crucial. As far as dictionary consultation is concerned, many scholars often lament the inadequacy of some legal bilingual dictionaries which generally list de-contextualized terms (De Groot and Van Laer 2008). Others criticize some online language resources, as they tend to be inaccurate or imprecise (Genette 2016; Giampieri 2016). 
What is generally preferable, is a combination of translation tools (Zanettin 2009; Giampieri 2018b), where corpora are consulted to corroborate or confute translation candidates, and are useful to show recurrent language patterns. Corpus consultation can also be very effective in order to tackle formulaic expressions (Vigier Moreno 2016: 105; Giampieri 2018a). Corpora help dispel linguistic doubts because they allow to choose the best translation candidates on the basis, for example, of collocational patterns (ibid.). Collocations represent the frequent co-occurrence of words (McEnery, Xiao and Tono 2006: 345). Corpora also show colligations (Sinclair 1991), which refer to the co-occurrence of a word with a particular grammatical class of words (McEnery, Xiao and Tono 2006: 345). Among the various types of corpora, comparable corpora are claimed to be very insightful (Giampieri 2018a), because they can "confirm translation hypotheses" (Zanettin 1998: 6) and provide reliable solutions to translation problems (Makowska 2016: 62). Comparable corpora are generally composed of source and target documents addressing the same topics (Laviosa 2002: 36; Zanettin 2012: 11). For this reason, they are considered an endless resource of equivalent terms (Makowska 2016: 62). They allow to discover the linguistic context of similar words (Biel 2008: 31) and help raise awareness on language conventions (Biel 2010: 13). Therefore, they are argued to be very useful for both translation training and practice (Zanettin 1998; Laursen and Pellón 2012).

Among the legal corpora available online, the Bononia Legal Corpus (Rossini Favretti, Tamburini and Martelli 2007) (henceforth the BoLC) is one of the most representative of its genre (Pontrandolfo 2012: 128). The BoLC is composed of two comparable sub-corpora (one Italian, one British) dealing with judiciary, parliamentary and statutory documents. The BoLC is advocated by linguists as it is a reliable tool for legal translations which helps dispel doubts (Rossini Favretti, Tamburini and Martelli 2007; Giampieri 2018a), especially if used jointly with other language resources (Giampieri 2018a).

In light of the challenges of legal discourse and of the claimed usefulness of comparable corpora for legal translations (Giampieri 2018a), this article will present a trial lesson with 10 experienced translators (9 Italian native speakers, one Polish), who participated in a 4-hour workshop. The translators had between 9 to 30 years' experience in technical translations. 
Before taking part in the workshop, the participants submitted a translation of a 300-word text dealing with a court case. The translation (from English to Italian) focused on a defense document issued by a defendant (an American company) in civil proceedings. During the workshop, the translators were explained the search syntax of the BoLC and they had the possibility to revise their translations in light of corpus evidence. Therefore, the approach followed by this case study was the following: submission of participants' draft translations and evaluation by the trainer; corpus search training, selfrevision of the translations by participants and second evaluation by the trainer.

\section{The case study}

The next pages will be dedicated to a thorough description of the case study. In particular, the following aspects will be tackled: the legal document which the participants translated; their background and experience in legal translations; the language resources used to translate the legal document; the challenges posed by the legal text and the way the translators addressed them before and after consulting the corpus.

Appendix 1 reports a quality questionnaire which the participants filled in after completing the translation task at home. The questionnaire focused on the translators' background and experience in technical and legal translations; the language resources they used to tackle the translation assignment; any difficult terms encountered during the translation process; the time taken to complete the task; the translators' native language(s) and their working language(s).

\section{Scope: participants and language resources}

The translators who participated in the workshop had an average of 10-15 years' work experience in technical translations. One had 9 years' experience; three over 20 (see Appendix 1, letter "A"). Their experience with legal translations varied from 0 (no experience) to 20 
years (Appendix 1, letter "B"). Many of them (especially those with not experience in legal translations) were trained in legal discourse and/or legal translations either at academic level or on a private basis. Those who received training privately participated in workshops or webinars dedicated to legal discourse and legal translations. All participants had Italian as their first language (only one was Polish) and translated from or into English (see Appendix 1, letter " $\mathrm{H}$ ").

As anticipated above, the participants firstly submitted a translation of a defense document. In order to complete the first translation task, the participants used the following language resources: Proz translators' forum (5 participants out of 10); multilingual platforms such as Reverso.net or Linguee.it (4 participants); legal online dictionaries such as legaldictionary.thefreedictionary.com or thelawdictionary.org; Wordreference online dictionary; the Eur-lex EU legal platform, and the IATE online dictionary ( 3 each). Table 1 reports these details.

Table 1: The language resources used to translate the legal text before the workshop

\begin{tabular}{|l|l|}
\hline \multicolumn{1}{|c|}{ Language Resource } & \multicolumn{1}{c|}{ Number of translators using it } \\
\hline Proz translators' forum & 5 \\
\hline $\begin{array}{l}\text { Multilingual platforms (Reverso.net, } \\
\text { Linguee.it, Glosbe My Memory) }\end{array}$ & 4 \\
\hline Eur-Lex EU legal platform & 3 \\
\hline $\begin{array}{l}\text { Legal dictionaries (online): legal- } \\
\text { dictionary.thefreedictionary.com; } \\
\text { thelawdictionary.org }\end{array}$ & 3 \\
\hline Wordreference & 3 \\
\hline IATE online dictionary & 3 \\
\hline $\begin{array}{l}\text { Dissertations on legal matters, law } \\
\text { journals, books on legal matters }\end{array}$ & 2 \\
\hline Generic online dictionaries & 2 \\
\hline Legal paper dictionaries & 2 \\
\hline $\begin{array}{l}\text { Sample contracts or sites dedicated to } \\
\text { international contracts }\end{array}$ & 2 \\
\hline
\end{tabular}




\begin{tabular}{|l|l|}
\hline Wikipedia & 2 \\
\hline Personal or online glossaries & 1 \\
\hline The Italian civil code & 1 \\
\hline Legal encyclopedia & 1 \\
\hline
\end{tabular}

As can be noticed, most of the participants heavily relied on past translators' choices (for example, they consulted the Proz forum or multilingual parallel platforms). It was, hence, evident that the majority followed peers' advice, rather than consulting technical dictionaries, legal documents, or scholars' research in legal matters. It would be interesting to investigate further and verify whether, on a larger scale, translators tend to rely more on the work of their peers than on field experts' knowledge and published materials.

The translations suggested by the participants were evaluated by the trainer before the workshop. The next paragraph will deal with the challenges posed by the legal document and how the participants tackled them.

\section{The legal document}

The attendants translated a legal document issued by an American company in its defense in a civil dispute. They translated the text from English to Italian; 9 participants out of 10 were Italian native speakers. The translation task had to be completed before attending the workshop and the participants were asked to indicate the language tools used to complete the task. In this way, it was possible to assess the translations before the trial lesson, and understand the language resources consulted.

The challenges posed by the legal document were undoubtedly related to formulaic expressions, collocations and the very precise terminology, which could not always be found on the web. Table 2 below summarizes the most difficult constructs on the basis of the translators' opinions (see Appendix 1, letter "E"). Furthermore, it highlights and comments on some challenging words or constructs. 
Patrizia Giampieri: The BoLC for Legal Translation...

Table 2 Challenges posed by the source text

\begin{tabular}{|c|c|c|c|}
\hline No. & Source text & $\begin{array}{l}\text { Translations proposed } \\
\text { by the participants }\end{array}$ & Challenges \\
\hline 1 & $\begin{array}{l}\text { Answer and } \\
\text { affirmative defense }\end{array}$ & $\begin{array}{l}\text {-Risposta e difesa } \\
\text { affermativa (literal } \\
\text { translation) } \\
\text {-Comparsa di } \\
\text { risposta e difesa per } \\
\text { cause esimenti } \\
\text { (back-translation: } \\
\text { "answer appearance } \\
\text { and defense for } \\
\text { justifications") }\end{array}$ & $\begin{array}{l}\text { Being a genre-specific } \\
\text { American-English term, } \\
\text { it was not easy to find it } \\
\text { on the web. }\end{array}$ \\
\hline 2 & Breach of contract & $\begin{array}{l}\text {-Inadempimento } \\
\text { contrattuale } \\
\text {-Inadempienza } \\
\text { contrattuale } \\
\text { (back-translation of } \\
\text { both: "non-fulfilment } \\
\text { of contract") } \\
\text {-Violazione del } \\
\text { contratto } \\
\text { (back-translation: } \\
\text { "violation of } \\
\text { contract") }\end{array}$ & $\begin{array}{l}\text { One might ask whether } \\
\text { the three translation } \\
\text { proposals are } \\
\text { equivalents. }\end{array}$ \\
\hline 3 & Plaintiff & $\begin{array}{l}\text {-Attore } \\
\text {-Ricorrente } \\
\text {-Querelante } \\
\text { (all translate } \\
\text { "Plaintiff") }\end{array}$ & $\begin{array}{l}\text { Dictionaries tend to } \\
\text { provide all three } \\
\text { translations. According } \\
\text { to the Italian legal } \\
\text { system, however, they } \\
\text { should not be used } \\
\text { interchangeably (see } \\
\text { lawyer's online } \\
\text { dictionary Brocardi). }\end{array}$ \\
\hline 4 & $\begin{array}{l}\text { Has failed to perform } \\
\text { its obligation }\end{array}$ & $\begin{array}{l}\text {-Non ha adempiuto } \\
\text {-Non ha ottemperato } \\
\text { (back-translations of } \\
\text { both: "[s/he] has not } \\
\text { fulfilled"; "[s/he] has } \\
\text { not complied with") }\end{array}$ & $\begin{array}{l}\text { It would be interesting } \\
\text { to verify which term is } \\
\text { more accurate and } \\
\text { recurrent in Italian legal } \\
\text { discourse. }\end{array}$ \\
\hline
\end{tabular}




\begin{tabular}{|c|c|c|c|}
\hline & & $\begin{array}{l}\text { - ....ai propri obblighi } \\
\text {-....alle proprie } \\
\text { obbligazioni } \\
\text { (back-translation of } \\
\text { both: "his/her own } \\
\text { obligations") }\end{array}$ & \\
\hline 5 & $\begin{array}{l}\text { Agreement, Paragraph } \\
3\end{array}$ & $\begin{array}{l}\text {-Accordo, paragrafo } \\
\text { (literal translation) }\end{array}$ & $\begin{array}{l}\text { Dictionaries tend to } \\
\text { propose a literal } \\
\text { translation of } \\
\text { "agreement" and } \\
\text { "paragraph". It would } \\
\text { be interesting to verify } \\
\text { whether this is } \\
\text { acceptable, or whether } \\
\text { there are other, more } \\
\text { suitable candidates. }\end{array}$ \\
\hline 6 & $\begin{array}{l}\text { Investment in cash and } \\
\text { in kind }\end{array}$ & $\begin{array}{l}\text {-Investimento in } \\
\text { denaro e in natura } \\
\text { (back-translation: } \\
\text { "investment in cash } \\
\text { and in nature") }\end{array}$ & $\begin{array}{l}\text { Is investimento in } \\
\text { natura (back-translated } \\
\text { "investment in nature") } \\
\text { frequent in Italian? Do } \\
\text { the words } \\
\text { "investimento" (back- } \\
\text { translated "investment") } \\
\text { and "natura" (back- } \\
\text { translated "nature") } \\
\text { collocate? }\end{array}$ \\
\hline 7 & Want of consideration & $\begin{array}{l}\text {-Difetto di } \\
\text { considerazione } \\
\text { (back-translation: } \\
\text { "defect of } \\
\text { consideration") } \\
\text {-Mancata } \\
\text { considerazione } \\
\text {-Mancata } \\
\text { considerazione } \\
\text { (back-translation: } \\
\text { "lack of } \\
\text { consideration") } \\
\text {-Mancata } \\
\text { controprestazione } \\
\text { (back-translation: } \\
\text { "lack of counter- } \\
\text { performance") }\end{array}$ & $\begin{array}{l}\text { The term } \\
\text { "consideration" is } \\
\text { contract-specific and not } \\
\text { all dictionaries or } \\
\text { language resources } \\
\text { might provide an } \\
\text { acceptable translation } \\
\text { candidate. It refers to } \\
\text { the reciprocal } \\
\text { performance in } \\
\text { a contractual obligation. }\end{array}$ \\
\hline
\end{tabular}


Patrizia Giampieri: The BoLC for Legal Translation...

\begin{tabular}{|c|c|c|c|}
\hline 8 & $\begin{array}{l}\text { Termination for breach } \\
\text { of contract }\end{array}$ & $\begin{array}{l}\text {-Cessazione del } \\
\text { contratto } \\
\text { (back-translation: } \\
\text { "cessation of the } \\
\text { contract") } \\
\text {-Scioglimento del } \\
\text { contratto } \\
\text { (back-translation: } \\
\text { "dissolution of } \\
\text { contract") } \\
\text {-Risoluzione del } \\
\text { contratto } \\
\text { (back-translation: } \\
\text { "cancellation of } \\
\text { contract") }\end{array}$ & $\begin{array}{l}\text { Are all translation } \\
\text { proposals synonyms in } \\
\text { the Italian legal } \\
\text { language? }\end{array}$ \\
\hline 9 & Unlawful penalty & $\begin{array}{l}\text {-Sanzione illegittima } \\
\text { (back-translated: } \\
\text { "illegitimate } \\
\text { sanction") } \\
\text {-Penale illecita } \\
\text {-Penale illegittima } \\
\text {-Penale illegale }\end{array}$ & $\begin{array}{l}\text { The terms illegittima } \\
\text { (back-translated } \\
\text { "illegitimate"), illecita } \\
\text { (back-translated } \\
\text { "illicit") and illegale } \\
\text { (back-translated } \\
\text { "illegal") have different } \\
\text { legal meanings } \\
\text { (Acquaviva 2018). }\end{array}$ \\
\hline 10 & $\begin{array}{l}\text { Not recoverable as } \\
\text { liquidated damages }\end{array}$ & $\begin{array}{l}\text {-Non recuperabile } \\
\text { come liquidazione dei } \\
\text { danni } \\
\text { (literal translation) } \\
\text {-Non prevede la } \\
\text { possibilità di } \\
\text { rimborso } \\
\text { (back-translated: } \\
\text { "does not foresee the } \\
\text { possibility of } \\
\text { reimbursement") }\end{array}$ & $\begin{array}{l}\text { The challenge lies in } \\
\text { "liquidated damages" } \\
\text { and in the adjective or } \\
\text { verb which collocate } \\
\text { with it ("recoverable" } \\
\text { and "foresee"). }\end{array}$ \\
\hline 11 & $\begin{array}{l}\text { And such other relief } \\
\text { as is just and proper }\end{array}$ & $\begin{array}{l}\text {-Qualsiasi altro } \\
\text { rilievo che sia giusto } \\
\text { e corretto } \\
\text {-Qualsiasi altro } \\
\text { rimedio equo e } \\
\text { appropriato } \\
\text {-Misura di ristoro } \\
\text { considerata equa e }\end{array}$ & $\begin{array}{l}\text { Could there be a fixed } \\
\text { formulaic expression? }\end{array}$ \\
\hline
\end{tabular}




\begin{tabular}{|l|l|l|}
\hline & $\begin{array}{l}\text { adeguata } \\
\text { (various literal } \\
\text { translations using } \\
\text { synonyms) }\end{array}$ & \\
\hline
\end{tabular}

As can be seen, the challenges posed by the source text were manifold, especially because of formulaic expressions, collocations, and/or system-specific terminology.

The majority of the translators took nearly an hour or a full hour to complete the task ( 5 out of 10); many took between 1 hour and a half and 2 hours (4); one took 4 hours (see Appendix 1, letter "F").

The participants' translations were submitted one week prior to the trial lesson.

\section{The trial lesson}

After evaluating the participants' translations, a workshop took place, where the challenges of the legal text and the shortcomings of the proposed translations were analyzed. In order to do so, the participants were trained in corpus consultation. In particular, they became acquainted with the BoLC, its search syntax and query symbols.

Querying the BoLC is not straightforward (see Giampieri 2018a). For example, it is not equipped with POS tagging (i.e., there is no linguistic annotation and it is not tagged with part of speech information). This makes the search syntax quite complex when investigating equivalence. For instance, if one wishes to look for lemmas, the Boolean operator OR (represented by the symbol "|") should be used together with a wide selection of verb forms.

After being explained the search syntax, the participants interrogated the Italian sub-corpus of the BoLC in order to corroborate or confute the translation candidates they had initially proposed. In this way, they could revise their translations in view of corpus evidence. 


\section{Approach}

After being trained in the use of the BoLC, the participants selfrevised their translations and verified the adequacy of their translation candidates in light of corpus evidence. The corpus analysis carried out by the participants was supervised by the trainer, who performed another evaluation of the translation proposals.

This paragraph will, hence, highlight how the participants interrogated the BoLC in order to retrieve sensible information. Furthermore, it will explore how corpus consultation helped refine translation work and confute or corroborate the translation candidates proposed by other language resources. Appendix 2 reports the BoLC query syntax and the results (or corpus evidence) obtained during the workshop. In practice, Appendix 2 draws on the challenging words or constructs of the legal documents (Table 2), and it shows how to dispel doubts by consulting the BoLC. The content of Appendix 2 will be discussed here below. The relevant search syntax will be explained and the results obtained from corpus evidence will be outlined.

As for the first term "Answer and affirmative defense" (Appendix 2, [1]), the participants were shown that the Hoepli online dictionary proposed "comparsa di costituzione" as a translation candidate of "answer". By searching for "comparsa di costituzione" in the Italian sub-corpus of the BoLC, it was possible to note it together with "con domanda riconvenzionale". This phrase translates "and affirmative defense". It goes without saying that further research on the web (for example on lawyers' web pages, or fora) would corroborate that an "Answer and affirmative defense" is the parallel of a Comparsa di costituzione con domanda (o eccezione) riconvenzionale. It is self-evident that sound knowledge of comparative law is necessary before engaging in legal translations, otherwise system-specific terminology might not be understood and/or rendered properly (De Groot and Van Laer 2008; Vigier Moreno and Sánchez Ramos 2017).

The term "breach of contract" (Appendix 2, [2]) was looked up in dictionaries. The Hoepli online dictionary suggested "inadempimento di contratto". In their home translations, the participants had proposed "inadempimento contrattuale", "inadempienza contrattuale" (both back-translated "non-fulfillment of contract") and "violazione contrattuale" (back-translated "violation of 
contract"). Therefore, the BoLC search string was the following: ("inadempimento" "contrattuale")|("inadempienza" "contrattuale") (back-translated: "non-fulfillment of contract" written with two different synonyms separated by the OR Boolean operator). In this way, it was possible to notice that "inadempimento" was more frequent. The same results were obtained by searching for "violazione contrattuale" ("violation of contract") and then "inadempimento contrattuale" (another way of saying "non-fulfilment of contract"). It was evident that the collocation "inadempimento contrattuale" was more frequent in the BoLC and its meaning in context was more adequate.

As far as "plaintiff" (Appendix 2, [3]) is concerned, the participants were invited to consult the Hoepli online dictionary, which suggested both "attore" and "ricorrente". These two terms are synonyms, but cannot be used interchangeably as the second one is used in particular cases envisaged by law (Giampieri 2017: 52). The differences could be grasped only by reading the literature in this field and/or lawyers' blogs or web pages addressing these terms (see Brocardi lawyers' online dictionary for an example). The translators had also found "querelante" in their home assignment. By searching for this term in the BoLC, however, it was possible to note that it was paired with criminal law terminology, such as "procedimento penale" or "processo penale" (criminal proceedings); "pubblico ministero" (public prosecutor or state's attorney), etc. Therefore, "querelante" was ruled out.

Regarding the formulaic expression "has failed to perform" (Appendix 2, [4]), the participants had proposed either "non ha adempiuto" (back-translated "[s/he] has not fulfilled") or "non ha ottemperato" ("[s/he] has not complied with"). The translators were invited to investigate which one was more frequent in the BoLC by writing the following search string: ("ottemperare"|"ottemperato"|"adempiere"|"adempiuto")(“obblighi”|" obbligazioni") (back-translated: "comply with OR complied with OR fulfill OR fulfilled" AND "obligations"). This phrase considers the verbs "ottemperare" ("comply with") and "adempiere" ("fulfill") in their infinitive and past participle forms. As the BoLC is not lemmatized, the infinitive and past participle forms of "ottemperare" ("comply with") and "adempiere" ("fulfill") had to be written in the search string, together with the two translations of "obligations" ("obbligazioni" and "obblighi"). The results were straightforward as 
"adempiere" was the only solution proposed, together with either "obbligazioni" or "obblighi" (both rendering "obligations").

As far as "agreement, paragraph" is concerned (Appendix 2, [5]), it can be argued that when searching for "agreement" in a dictionary, the translation candidates "accordo" and "contratto" came to the fore. When looking for "paragraph", instead, the translations "paragrafo" and "comma" were suggested. However, by writing ("del" "contratto")|(“dell" [] "accord") (back-translated "of the contract" OR "of the agreement"), it was possible to note that "contratto" (back-translated "contract") was by far more frequent than "accordo" (back-translated "agreement"), and "articolo" ("article") or "clausola" ("clause") appeared quite often before "del contratto" ("of the contract"). Hence, the correct translation of "paragraph" was neither "paragrafo" nor "comma" in a contract or an agreement, but "clausola" ("clause") or "articolo" ("article"). In order to dispel doubts, the following search string was suggested: ("articolo"|"clausola") [] $\{0,3\}$ "contratto" (back-translated: "article OR clause ... contract"). The []$\{0,3\}$ command instructed the system to search from 0 to 3 characters between the two word groups. It was evident that "clausola" ("clause") prevailed over "articolo" ("article").

Regarding the formula "investment in cash and in kind" (Appendix 2, [6]), the Hoepli online dictionary clearly specified that "in kind" means "in natura". By searching for ("investimento"|"investimenti") "in" "natura" ("investment OR investments in nature") in the BoLC, no hits could be found. This suggested that there must have been another formulaic expression. By simply writing "in" "natura" ("in nature"), it was possible to notice the word "conferimenti" (back-translated "contributions") which preceded it. Therefore, the formula "conferimenti in denaro $e$ in natura" ("contributions in cash and in kind") was the correct solution.

As for "want of consideration" (Appendix 2, [7]), the majority of the translators had proposed literal rendering, such as "mancata considerazione" ("lack of consideration"), or "difetto di considerazione" ("defect of consideration"). Some others had suggested "mancata controprestazione" ("lack of counterperformace"). In order to either confute or corroborate these translation candidates, the string ("difetto"|"mancata"|"mancanza") [] $\{0,4\}$ ("controprestazione"|"considerazione") was written (backtranslated: "defect OR lack" ... "consideration OR counter- 
performance"). The concordances obtained showed many "considerazione" ("consideration"). However, the meanings in context of this word were "attention" or "thoughtfulness", which were far from the original "want of consideration". The latter, in fact, referred to the lack of reciprocal performance in a contractual obligation. By taking out "considerazione" from the search string, it was possible to notice a few concordance lines with "mancata controprestazione" or "mancanza di una controprestazione" (back-translated: "lack of (a) counter-performance"). Therefore, the most appropriate term was "controprestazione" (back-translated: "counter-performance").

The meaning and use of the term "termination" in a contract (Appendix 2, [8]) is fully addressed by the American law (see, for example, the UCC 1972). The same can be said of its translation candidates (Giampieri 2016). Nonetheless, not all dictionaries propose a consistent rendering, especially because its translations depend on the reference legal system. However, as the subject matter in question was a breach of contract, the search query was the following: "contratto" []\{0,5\} "inadempimento" (back-translated: "contract... breach"). In this way, it was possible to search for translation equivalents of "termination for breach of contract". Concordance lines with "risoluzione del contratto per inadempimento" (back-translated: "termination/cancellation of contract for breach") came to the fore. Hence, in this context, the translation of "termination" was "risoluzione".

As far as "unlawful penalty" is concerned (Appendix 2, [9]), unfortunately the BoLC provided too many hits with "penale", "clausola penale" or "sanzione penale" (all translating "penalty"). The suggested search syntax was then the following: (“clausola"|"penale") (“illegittima"|"illecita"|"illegal") (backtranslated: "clause OR penalty" AND "illegitimate OR illicit OR illegal"). However, the corpus proposed both "clausola illegittima" and "clausola illecita". Therefore, other language resources had to be consulted in order to dispel doubts. In this case, the Garzanti Italian dictionary and the Italian Treccani encyclopedia provided satisfactory explanations of the differences between "illegittimo" (back-translated "illegitimate"), "illecito" (back-translated "illicit"), and "illegale" (back-translated "illegal"). After reading the explanations, the participants found that "illegittima" was an acceptable translation candidate of "unlawful", as it related to something which does not comply with the law owing to flaws. 


\section{Patrizia Giampieri: The BoLC for Legal Translation...}

In the phrase "not recoverable as liquidated damages" (Appendix 2, [10]), the participants were confronted with both the translation of the term "liquidated damages" and the adjective or verb which collocate with it. "Liquidated damages" was not listed in many online dictionaries. However, accurate web research could provide sound explanations and a translation. For instance, Italian lawyers' blogs (see Bianchi 2012) or publishing houses' web articles (see De Palma 2010) clearly stated that a liquidated damages clause concern the damages which a party claims from the other party in case of a breach of contract. Therefore, the term "damages" was a synonym of "liquidated damages" and was translated "risarcimento del danno" in most dictionaries. The BoLC search string was then the following: "non" []\{0,5\} "risarcimento" "Danni" (back-translated: "not... liquidated damages") or "non" []$\{0,2\}$ "come" []$\{0,5\}$ "risarcimento" (back-translated: "not... as... liquidated damages"). In both cases, the verb "si configura" (back-translated "is classified/considered") came to the fore.

Regarding the closing phrase "and such other relief as is just and proper" (Appendix 2, [11]), the participants had proposed several translation candidates. By consulting the Garzanti online dictionary, it was possible to note that the translation of "relief" was "riparazione" (back-translated "repair"). Therefore, the BoLC search string was as follows:

("riparazione")

("equa"|"corretta"|"adeguata"|"giusta"). ("repair .... fair OR right OR adequate OR just"). The participants noted that some of the adjectives which followed "riparazione" were the ones they had suggested. For example, the BoLC showed a concordance line with "ogni altra riparazione adeguata" (back-translated: "any other adequate repair").

The new translation candidates were evaluated by the trainer and they were found satisfactory. It goes without saying that, in order to obtain sensible results from the BoLC, users needed to know how to navigate through its data. To some extent, they also needed to "play with words" in order to formulate search queries which could lead to meaningful results. In this sense, the BoLC search syntax was not particularly straightforward. However, once mastered, it led to very insightful findings. 
7. Findings: advantages and shortcomings of the BoLC

On the basis of the participants' suggested translations, of their search for the best candidates and of the results obtained, it can be argued that the BoLC was a reliable source of legal language which helped dispel doubts. Despite its complex search query, the results obtained were very satisfactory. As could be noticed during the trial lesson, in fact, the BoLC helped increase the user's confidence (FrankenbergGarcia 2015: 353) and translate more accurately (Giampieri 2018a). Albeit consulting multilingual platforms and online multilingual dictionaries, it was apparent that the participants' translation candidates were sometimes inaccurate or imprecise (see [3], [6] and [9] in Appendix 2). This, however, could have been due to the fact that some translators had little or no experience in legal texts and for some translators (namely 5), English was not the only working language.

Nonetheless, in some cases the BoLC did not provide satisfactory answers. For example, the term "answer and affirmative defense" (in [1]) belongs to American civil proceedings and it was probably too specific and out of the BoLC remit."Plaintiff" (in [3]), instead, was perhaps too generic. In [9], the search for the translation candidates of "unlawful penalty" was not successful. Therefore, knowledge of comparative law and/or the consultation of legal documentation was an unquestionable prerequisite, as the corpus alone could not provide sufficient evidence.

Furthermore, it goes without saying that translation candidates had firstly to be searched either online or in dictionaries, before being entered in the BoLC search string. Translators' intuition was probably not developed enough to suggest the terms to search in the corpus (Bowker and Pearson 2002: 14). This, however, should not be considered a drawback. The literature, in fact, reports that corpora are language tools which can, or should, be used in conjunction with other language resources such as dictionaries (Zanettin 2009; Biel 2010; Giampieri 2018b).

In light of the above, it can be speculated that knowledge of comparative law regarding the subject matter is essential, in order to deliver accurate legal translation work. Moreover, a joint use of several language resources would be advisable (Giampieri 2018b), 
together with the consultation of a legal corpus, of field-specific documents and of the literature.

\section{Conclusions}

The trial lesson with 10 experienced translators showed that sometimes legal discourse cannot be tackled only by relying on dictionary entries, past translators' choices, or by consulting online multilingual platforms. Dictionary suggestions and multilingual platforms can, in fact, be biased due to lack of consideration of the system-specificity of the searched terms.

The workshop findings remarked the importance of using a variety of language resources in order to deliver accurate translation work. Therefore, several sector-specific documents (such as lawyers' draft documents, lawyers' blogs, acts or contracts) should be consulted, in order to find reliable technical words. In addition, querying a corpus can be useful, as it helps dispel doubts as far as collocations, colligations and formulaic expressions are concerned. For example, in cases where the translators' intuition could not help find acceptable candidates, dictionaries proved to be of great help. Dictionary entries, however, should be corroborated or confuted by corpus evidence.

Despite the many advantages of the BoLC, the trial lesson also brought to the fore some of its drawbacks. For example, the BoLC is not lemmatized and the search syntax is rather complex, especially if one wishes to carry out accurate research. Therefore, terms whose meaning is too broad or complex may be hard to find, due to the impossibility of narrowing down the search. A good way of tackling the complexity of the BoLC search syntax is to "play with words" and write search queries by using Boolean operators to find meaningful results. For these reasons, once its syntax is mastered, the BoLC is a reliable legal language tool which helps deliver accurate translation work, especially if used in combination with other language resources. 


\section{Bibliography}

Abate, Claudio. 1998. Il documento legale anglosassone. Milan: Hoepli.

Acquaviva, Mariano. 2018. Web article.

https://www.laleggepertutti.it/190848_cosa-vuol-dire-illegale (accessed June, 18 2019).

Bhatia, Vijay Kumar. 1993. Analysing Genre: Language Use in Professional Settings. London: Longman.

Bhatia, Vijay Kumar, Nicola M. Langton, and Jane Lung. 2004. Legal discourse: Opportunities and threats for corpus linguistics. In Discourse in the Professions. Perspectives from Corpus

Linguistics. ed. Ulla Connor, and Thomas A. Upton. 203-231. Amsterdam/Philadelphia: John Benjamins.

Bianchi, Marco. 2012.

https://contrattiinternazionalidimarcobianchi.it/clausolapenale-v-clausola-di-liquidated-damages/ (accessed June, 18 2019).

Biel, Łucja. 2008. Legal terminology in translation practice: dictionaries, googling or discussion forums? SKASE Journal of Translation and Interpretation 3: 22-38.

Biel, Łucja. 2010. Corpus-Based Studies of Legal Language for Translation Purposes: Methodological and Practical Potential. In Reconceptualizing LSP. Online proceedings of the XVII European LSP Symposium 2009. ed. Carmen Heine, and Jan Engberg, 1-19.

Biel, Łucja and Jan Engberg. 2013. Research models and methods in legal translation. Linguistica Antverpiensia - New Themes in Translation Studies 12: 1-11.

Bowker, Lynne and Jennifer Pearson. 2002. Working with specialized language - A practical guide to using corpora. London and New York: Routledge.

Coulthard, Malcolm and Alison Johnson. 2007. An Introduction to Forensic Linguistics - Language in Evidence. New York: Routledge.

Coulthard Malcolm and Alison Johnson 2010. The Routledge Handbook of Forensic Linguistics. Abingdon: Routledge. 
De Groot, Gerard René and Conrad J. P. Van Laer. 2008. The Quality of Legal Dictionaries: an assessment. Maastricht: University of Maastricht.

De Palma, Serena. 2010. https://www.filodiritto.com/articoli/2010/02/i-rimedicontrattuali-allinadempimento-penalty-clause-e-liquidateddamages-clause (accessed June, 18 2019).

Frankenberg-Garcia, Ana. 2015. Training translators to use corpora hands-on: challenges and reactions by a group of 13 students at a UK university. Corpora 10 (2): 351-380.

Genette, Marie. 2016. How reliable are online bilingual concordancers? An investigation of Linguee, TradoolT, WeBiText and ReversoContext and their reliability through a contrastive analysis of complex prepositions from French to English. Master's Thesis. https://www.duo.uio.no/bitstream/handle/10852/51577/MAthe sis_Marie_GENETTE.pdf?sequence=1\&isAllowed=y (accessed June, 18 2019).

Giampieri, Patrizia 2016. A Critical Compartive Analysis of Online Tools for Legal Translations. The Italian Law Journal 2(2): 445-461.

Giampieri, Patrizia. 2017. Legal English per avvocati e traduttori. [Legal English for lawyers and translators]. Milan: Giuffrè.

Giampieri, Patrizia. 2018a. Online parallel and comparable corpora for legal translations. Altre Modernità, 20: 237-252.

Giampieri, Patrizia. 2018b. The web as corpus and online corpora for legal translations. Comparative Legilinguistics 33: 35-55.

Laursen, Anne Lise and Ismael Arinas Pellón. 2012. Text Corpora in Translator Training. The Interpreter and Translator Trainer 6(1): 45-70.

Laviosa, Sara. 2002. Corpus-based Translation Studies. Theory, Findings, Applications. Ámsterdam / Nueva York: Rodopi.

Makowska Aleksandra. 2016. Creating multilingual corpora to teach scientific translation. In New Insights into Corpora and Translation, ed. Daniel Gallego-Hernández, 57-77. Newcastle upon Tyne: Cambridge Scholars Publishing.

McEnery, Tony, Richard Xiao, and Yukio Tono. 2006. Corpus-Based Language Studies: An Advanced Resource Book. New York: Routledge.

Rossini Favretti, Rema, Fabio Tamburini, and Enrico Martelli. 2007. 
Words from Bononia Legal Corpus. In Text Corpora and Multilingual Lexicography, ed. Wolfgang Tuebert, 11-30. Amsterdam: John Benjamins.

Sinclair, John. 1991. Corpus, concordance, collocation. Oxford: Oxford University Press.

Tiersma, Peter. 1999. Legal Language. University of Chicago Press.

Tiersma, Peter, and Lawrence M. Solan. 2012. The Oxford Handbook of Language and Law. New York: Oxford University Press.

Uniform Commercial Code (UCC) Act 174 of 1962. Available at: https://www.michigan.gov/documents/entireuccbook_18831_ 7.pdf courtesy of www.legislature.mi.gov

Vigier Moreno, Francisco J. 2016. Teaching the Use of ad hoc Corpora. Language and Law / Linguagem e Direito 3(1): 100119.

Vigier Moreno, Francisco J. and Maria del Mar Sánchez Ramos. 2017. Using Parallel Corpora to Study the Translation of Legal System-Bound Terms: The Case of Names of English and Spanish Courts. In Computational and Corpus-Based Phraseology. Second International Conference, Eu-rophras 2017 London, UK, November 13-14, 2017 Proceedings, ed. Ruslan Mitkov, 260-273. Cham: Springer.

Williams, Christopher. 2004. Legal English and Plain Language: an introduction. ESP Across Cultures 1: 111-124.

Zanettin, Federico. 1998. Bilingual Comparable Corpora and the Training of Translators. Meta : journal des traducteurs / Meta: Translators' Journal 43(4): 616-630.

Zanettin, Federico. 2009. Corpus-based Translation Activities for Language Learners. The Interpreter and Translator Trainer 3(2): 209-24.

Zanettin, Federico. 2012. Translation-Driven Corpora: Corpus Resources for Descriptive and Applied Translation Studies. London: Routledge.

\section{Online resources:}

Brocardi lawyers' online dictionary: https://www.brocardi.it/dizionario/3566.html

Garzanti dictionary: www.garzantilinguistica.it Hoepli dictionary: www.dizionari.repubblica.it Treccani encyclopedia: http://www.treccani.it/enciclopedia/ 
Patrizia Giampieri: The BoLC for Legal Translation...

\section{Appendix 1: Questionnaire}

\begin{tabular}{|c|c|c|c|c|c|c|c|c|c|c|}
\hline \begin{tabular}{|l} 
Que \\
stio \\
ns
\end{tabular} & $\begin{array}{l}\text { Transl } \\
\text { ator } 1\end{array}$ & $\begin{array}{l}\text { Tran } \\
\text { slato } \\
\text { r } 2\end{array}$ & \begin{tabular}{|l} 
Tran \\
slato \\
r 3
\end{tabular} & $\begin{array}{l}\text { Transl } \\
\text { ator } 4\end{array}$ & $\begin{array}{l}\text { Tran } \\
\text { slato } \\
\text { r } 5\end{array}$ & $\begin{array}{l}\text { Transl } \\
\text { ator } 6\end{array}$ & $\begin{array}{l}\text { Tran } \\
\text { slato } \\
\text { r } 7\end{array}$ & $\begin{array}{l}\text { Transl } \\
\text { ator } 8\end{array}$ & $\begin{array}{l}\text { Trans1 } \\
\text { ator } 9\end{array}$ & $\begin{array}{l}\text { Trans } \\
\text { lator } \\
10\end{array}$ \\
\hline A & 15 & 20 & 30 & 11 & 24 & 10 & 15 & 15 & 9 & 10 \\
\hline B & - & 20 & 20 & 11 & - & 3 & 15 & 3 & 9 & 5 \\
\hline $\mathrm{C}$ & $\begin{array}{l}\text { Enroll } \\
\text { ed in } \\
\text { a } \\
\text { maste } \\
\text { r's } \\
\text { course } \\
\text { in law }\end{array}$ & \begin{tabular}{|l} 
Exa \\
ms at \\
univ \\
ersit \\
$y ;$ \\
vario \\
us \\
work \\
shop \\
s \\
\end{tabular} & - & $\begin{array}{l}\text { On } \\
\text { the } \\
\text { job } \\
\text { trainin } \\
\mathrm{g} \text { (in } \\
\text { intern } \\
\text { ationa } \\
1 \\
\text { firms) }\end{array}$ & $\begin{array}{l}\text { Wor } \\
\text { ksho } \\
\text { ps on } \\
\text { legal } \\
\text { texts } \\
\text { and } \\
\text { trans } \\
\text { latio } \\
\text { ns }\end{array}$ & - & $\begin{array}{l}\text { Wor } \\
\text { ksho } \\
\text { ps on } \\
\text { legal } \\
\text { texts } \\
\text { and } \\
\text { trans } \\
\text { latio } \\
\text { ns }\end{array}$ & - & $\begin{array}{l}\text { Works } \\
\text { hops } \\
\text { and } \\
\text { webin } \\
\text { ars on } \\
\text { legal } \\
\text { transl } \\
\text { ations }\end{array}$ & - \\
\hline D & $\begin{array}{l}1,2,4 \\
6,13\end{array}$ & $\begin{array}{l}3,5,6 \\
, 8,9\end{array}$ & $\begin{array}{l}1,10 \\
, 11\end{array}$ & $\begin{array}{l}6,7,10 \\
12\end{array}$ & $\begin{array}{l}5,6,1 \\
1\end{array}$ & 7,15 & $\begin{array}{l}5,11 \\
12,1 \\
4\end{array}$ & $\begin{array}{l}8,13,1 \\
4\end{array}$ & $\begin{array}{l}1,3,7 \\
10,11 \\
15\end{array}$ & 6 \\
\hline $\mathrm{E}$ & $\begin{array}{l}\text { consid } \\
\text { eratio } \\
\mathrm{n}, \\
\text { termin } \\
\text { ation }\end{array}$ & \begin{tabular}{|l} 
affir \\
mati \\
ve \\
defe \\
nse, \\
on or \\
abou \\
t, \\
termi \\
natio \\
$n$
\end{tabular} & - & $\begin{array}{l}\text { want } \\
\text { of } \\
\text { consid } \\
\text { eratio } \\
\mathrm{n}, \\
\text { affirm } \\
\text { ative } \\
\text { defens } \\
\text { e }\end{array}$ & $\begin{array}{l}\text { an } \\
\text { entir } \\
\text { e } \\
\text { para } \\
\text { grap } \\
\text { h }\end{array}$ & $\begin{array}{l}\text { affirm } \\
\text { ative } \\
\text { defens } \\
\text { e, } \\
\text { want } \\
\text { of } \\
\text { consid } \\
\text { eratio } \\
\text { n, } \\
\text { factua } \\
1 \\
\text { basis, } \\
\text { relief }\end{array}$ & $\begin{array}{l}\text { wher } \\
\text { efore } \\
\text {, for } \\
\text { all } \\
\text { the } \\
\text { foreg } \\
\text { oing } \\
\text { reaso } \\
\text { ns, } \\
\text { just } \\
\text { and } \\
\text { prop } \\
\text { er, } \\
\text { other } \\
\text { relief } \\
\text {, } \\
\text { pena } \\
\text { lty, } \\
\text { liqui } \\
\text { date } \\
\text { d } \\
\text { dam } \\
\text { ages }\end{array}$ & $\begin{array}{l}\text { want } \\
\text { of } \\
\text { consid } \\
\text { eratio } \\
n, \\
\text { penalt } \\
y\end{array}$ & $\begin{array}{l}\text { want } \\
\text { of } \\
\text { consid } \\
\text { eratio } \\
n\end{array}$ & $\begin{array}{l}\text { termi } \\
\text { natio } \\
\mathrm{n}, \\
\text { liqui } \\
\text { dated } \\
\text { dama } \\
\text { ges }\end{array}$ \\
\hline
\end{tabular}


Comparative Legilinguistics 39/2019

\begin{tabular}{|c|c|c|c|c|c|c|c|c|c|c|}
\hline $\mathrm{F}$ & $\begin{array}{l}50 \\
\text { mins. }\end{array}$ & $1 \mathrm{hr}$. & $\begin{array}{l}2 \\
\text { hrs. }\end{array}$ & $1 \mathrm{hr}$ & $\begin{array}{l}4 \\
\text { hrs. }\end{array}$ & $1,5 \mathrm{hr}$. & $\begin{array}{l}45 \\
\operatorname{mins}\end{array}$ & $\begin{array}{l}1 \mathrm{hr} \\
45 \\
\text { mins. }\end{array}$ & $2 \mathrm{hrs}$. & $\begin{array}{l}40 \\
\text { mins. }\end{array}$ \\
\hline G & Yes & Yes & $\begin{array}{l}\text { No } \\
\text { (Pol } \\
\text { ish) }\end{array}$ & Yes & Yes & Yes & Yes & Yes & Yes & Yes \\
\hline $\mathrm{H}$ & Yes & $\begin{array}{l}\text { I } \\
\text { also } \\
\text { trans } \\
\text { late } \\
\text { from } \\
\text { /to } \\
\text { Russ } \\
\text { ian }\end{array}$ & $\begin{array}{l}\text { I } \\
\text { also } \\
\text { tran } \\
\text { slate } \\
\text { fro } \\
\text { m/to } \\
\text { Poli } \\
\text { sh }\end{array}$ & $\begin{array}{l}\text { I also } \\
\text { transl } \\
\text { ate } \\
\text { from/t } \\
\text { o } \\
\text { Germ } \\
\text { an }\end{array}$ & Yes & Yes & $\begin{array}{l}\text { I } \\
\text { also } \\
\text { trans } \\
\text { late } \\
\text { from } \\
\text { /to } \\
\text { Ger } \\
\text { man }\end{array}$ & Yes & $\begin{array}{l}\text { I also } \\
\text { transl } \\
\text { ate } \\
\text { from/t } \\
\text { o } \\
\text { Czech } \\
\text { and } \\
\text { Slova } \\
\text { k) }\end{array}$ & Yes \\
\hline
\end{tabular}

Question list:

A: Years of experience as a translator.

B: Do you have experience in legal translations? If yes, how many years?

$\mathrm{C}$ : Did you undertake any training in legal discourse/translations?

D: Language tools and resources you used for your translation.

\section{IATE}

2.Personal glossaries

3. Online glossaries

4.The Italian civil code

5.Wordreference

6.Proz translator's forum

7.Legal dictionaries (online): legal-dictionary.thefreedictionary.com; thelawdictionary.org

8.Legal dictionaries (paper)

9.Legal encyclopedia

10.Eur-Lex

11.Glosbe My Memory, Reverso.net, Linguee.it

12.Wikipedia

13.Generic online dictionaries

14.Sample contracts or sites dedicated to international contracts

15.Dissertations, law journals, books on legal matters

E: Did you find any difficult terms? If yes, which ones?

F: Time to deliver the translation.

G: Is Italian your mother tongue?

H: Is English mostly your source or target language? 
Patrizia Giampieri: The BoLC for Legal Translation...

Appendix 2: Investigating the Italian sub-corpus of the BoLC

\begin{tabular}{|c|c|c|c|}
\hline No. & Source text & BoLC search syntax & Results/corpus evidence \\
\hline 1 & $\begin{array}{l}\text { Answer and } \\
\text { affirmative } \\
\text { defense }\end{array}$ & $\begin{array}{l}\text { "comparsa" "di" } \\
\text { "costituzione", }\end{array}$ & $\begin{array}{l}\text { In some concordance lines } \\
\text { it is possible to note "con } \\
\text { domanda riconvenzionale" } \\
\text { which follows "comparsa } \\
\text { di costituzione". }\end{array}$ \\
\hline 2 & $\begin{array}{l}\text { Breach of } \\
\text { contract }\end{array}$ & 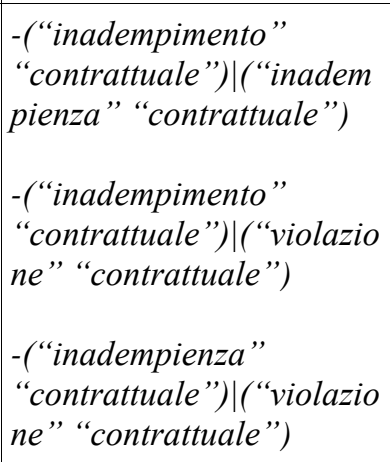 & $\begin{array}{l}\text { The phrase } \\
\text { "inadempimento } \\
\text { contrattuale" is more } \\
\text { frequent. }\end{array}$ \\
\hline 3 & Plaintiff & "querelante" & $\begin{array}{l}\text { If "querelante" is searched, } \\
\text { it can be noticed that this } \\
\text { term is used in criminal } \\
\text { cases. } \\
\text { As for "ricorrente" and } \\
\text { "attore", only accurate } \\
\text { search in the literature or in } \\
\text { lawyers" blogs/web pages } \\
\text { can dispel doubts about } \\
\text { their legal differences. }\end{array}$ \\
\hline 4 & $\begin{array}{l}\text { Has failed to } \\
\text { perform its } \\
\text { obligation }\end{array}$ & 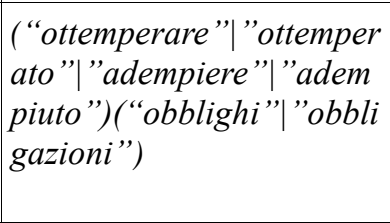 & $\begin{array}{l}\text { The verb "adempiere" is } \\
\text { the only one found. } \\
\text { The nouns "obblighi" and } \\
\text { "obbligazioni" are both } \\
\text { present. }\end{array}$ \\
\hline 5 & $\begin{array}{l}\text { Agreement, } \\
\text { Paragraph } 3\end{array}$ & $\begin{array}{l}\text { (“del” } \\
\text { “contratto”)|("dell” } \\
\text { "accord”) }\end{array}$ & $\begin{array}{l}\text { "Clausola" frequently } \\
\text { precedes "contratto". }\end{array}$ \\
\hline 6 & $\begin{array}{l}\text { Investment in } \\
\text { cash and in } \\
\text { kind }\end{array}$ & “in" "natura”, & $\begin{array}{l}\text { By searching for "in } \\
\text { natura", it is possible to } \\
\text { notice the word } \\
\text { "conferimenti" (back- } \\
\text { translated "contributions") }\end{array}$ \\
\hline
\end{tabular}


Comparative Legilinguistics 39/2019

\begin{tabular}{|c|c|c|c|}
\hline & & & which precedes it. \\
\hline 7 & $\begin{array}{l}\text { Want of } \\
\text { consideration }\end{array}$ & $\begin{array}{l}\text { (“difetto"|"mancata"|"m } \\
\text { ancanza") }[]\{0,4\} \\
\text { ("controprestazione”|"co } \\
\text { nsiderazione") }\end{array}$ & $\begin{array}{l}\text { By reading the } \\
\text { concordances, it is evident } \\
\text { that "considerazione" } \\
\text { means "thoughtfulness" } \\
\text { and is not consistent with } \\
\text { the legal subject matter. } \\
\text { "Controprestazione" is } \\
\text { more appropriate. } \\
\text { "Mancanza" and } \\
\text { "mancata" prevail over } \\
\text { "difetto". }\end{array}$ \\
\hline 8 & $\begin{array}{l}\text { Termination } \\
\text { for breach of } \\
\text { contract }\end{array}$ & $\begin{array}{l}\text { "contratto" }[]\{0,5\} \\
\text { "inadempimento" }\end{array}$ & $\begin{array}{l}\text { It is possible to notice the } \\
\text { collocate "risoluzione" } \\
\text { which precedes } \\
\text { "contratto... } \\
\text { inadempimento" (back- } \\
\text { translated "contract... } \\
\text { breach"). Hence, } \\
\text { "risoluzione" translates } \\
\text { "termination". }\end{array}$ \\
\hline 9 & $\begin{array}{l}\text { Unlawful } \\
\text { penalty }\end{array}$ & $\begin{array}{l}\text { (“clausola”|"penale") } \\
\text { ("illegittima",|"illecita”|" } \\
\text { illegal") }\end{array}$ & $\begin{array}{l}\text { Corpus evidence shows } \\
\text { both "clausola illegittima" } \\
\text { and "clausola illecita". In } \\
\text { this case only an Italian } \\
\text { dictionary or encyclopedia } \\
\text { can help understand the } \\
\text { differences between the } \\
\text { various translation } \\
\text { candidates. }\end{array}$ \\
\hline 10 & $\begin{array}{l}\text { Not } \\
\text { recoverable as } \\
\text { liquidated } \\
\text { damages }\end{array}$ & $\begin{array}{l}\text { - "non” }[]\{0,5\} \\
\text { "risarcimento" “danni” } \\
\text { - “non” }[]\{0,2\} \text { “come”, } \\
{[]\{0,5\} \text { "risarcimento" }}\end{array}$ & $\begin{array}{l}\text { The English term } \\
\text { "liquidated damages" is } \\
\text { explained and translated } \\
\text { "risarcimento (danni)" in } \\
\text { many lawyers' blogs and } \\
\text { posts. } \\
\text { The search string helps } \\
\text { find the collocates of } \\
\text { "risarcimento". In both } \\
\text { cases, the verb "si } \\
\text { configura" (back-translated } \\
\text { "(is) classified") is found. }\end{array}$ \\
\hline
\end{tabular}


Patrizia Giampieri: The BoLC for Legal Translation...

\begin{tabular}{|l|l|l|l|}
\hline 11 & $\begin{array}{l}\text { And such } \\
\text { other relief as } \\
\text { is just and } \\
\text { proper }\end{array}$ & $\begin{array}{l}\text { ("riparazione") }[]\{0,5\} \\
\text { ("equa"|"corretta"|"adeg } \\
\text { uata"|"giusta") }\end{array}$ & $\begin{array}{l}\text { The term "riparazione" } \\
\text { ("repair") is listed in the } \\
\text { Garzanti online dictionary. } \\
\text { The adjectives which } \\
\text { follow are those suggested } \\
\text { by the participants. Both } \\
\text { "equa" and "adeguata" are } \\
\text { found in the BoLC. }\end{array}$ \\
\hline
\end{tabular}

